Original research article

\title{
Effectiveness of care of patients with diabetes mellitus in the context of Wagner's model
}

\author{
L'ubomíra Tkáčová *, Dagmar Magurová, Beáta Grešš Halász, L'udmila Majerníková \\ University of Prešov, Faculty of Health Care, Department of Nursing, Prešov, Slovak Republic
}

\begin{abstract}
Introduction: In the 21st century, the number of chronic diseases has increased significantly. Doctor Wagner and his team presented the most influential theoretical model of care for the chronically ill - the Chronic Care Model - CCM.

Design: The presented paper analyses the results obtained by quantitative research.

Objective: The objective of this quantitative research was to find out the effectiveness of individual elements of Wagner's model (CCM) in the care of patients with diabetes mellitus, depending on the type of treatment.

Methods: The total sample consisted of 1,511 respondents. The selection of respondents was based on stratified selection. The data collection tool used was the standardized PACIC+ questionnaire.

Results: By examining the effectiveness of evaluation of care for DM patients (depending on the type of treatment) we found that there is a significant relationship among variables. Patients, who use an insulin pump, positively evaluate most of the elements of CCM. On the contrary, patients treated with anti-diabetics report the worst rating. The greatest differences were found in patients' satisfaction with the overall organization of care. Patients with an insulin pump were most satisfied (mean 3.60), patients on insulin pens were less satisfied (mean 3.33), and the least satisfied were patients treated with PAD (peroral anti-diabetics) (mean 3.17).

Conclusion: Wagner's model has the potential to improve the efficiency of care for patients with diabetes mellitus without an adverse effect on patient outcomes.
\end{abstract}

Keywords: Diabetes mellitus; Efficiency; Chronic diseases; Nursing; Wagner's model

\section{Introduction}

Chronic diseases are one of the biggest challenges facing the healthcare systems in the 21st century. According to WHO (2018), 15 million people aged 30 to 69 die each year from chronic diseases. Cardiovascular disease is the cause of death of 17.9 million people per year, followed by cancer (9.0 million), respiratory diseases (3.9 million) and diabetes mellitus (1.6 million). These four groups of diseases account for more than $80 \%$ of all premature deaths from chronic diseases (WHO, 2018). Patients with chronic diseases need a high level of support within their communities to ensure the highest quality of life. A cost-effective and pragmatic approach must be used to ensure that the care is appropriate, financially accessible, and affordable to all patients with chronic disease - along with possible access to specialized care and management. Applying innovation in the care of chronically ill patients means introducing new ideas, methods, programs or models to revolutionise the way in which secondary and subsequent prevention and treatment of chronic diseases are changed (Tkáčová et al., 2019).
Dr Wagner and his colleagues presented perhaps the most influential theoretical model of care for the chronically ill (the Chronic Care Model - CCM). This model consists of four interconnected system components that are considered the key to providing quality care for people with chronic illness: (1) Self-management support; (2) Design of care system; (3) Decision support; (4) Clinical information systems. These components are embedded in the context of a healthcare system that links an appropriately organized healthcare service delivery system with complementary community resources and healthcare policy (Simmons et al., 2016).

The model was developed based on a thorough knowledge of the theoretical basis of the available literature sources related to the issue of managing chronic diseases in response to a medical situation involving a high incidence of chronic diseases and the failure of healthcare systems in the United States. Based on this model, the authors believe that people will be better managed and will live a healthier lifestyle. This is how parallel healthcare costs will be reduced if this model is used. This care model applies a patient-centred approach through partnership, not only with the patient themselves, but also with other healthcare professionals to optimize health outcomes (Garnelo et al., 2014).

\footnotetext{
* Author for correspondence: L'ubomíra Tkáčová, University of Prešov, Faculty of Health Care, Department of Nursing, Partizánska 1, 08001 Prešov, Slovak Republic; e-mail: lubomira.tkacova@unipo.sk http://doi.org/10.32725/kont.2020.009

Submitted: 2019-05-06 • Accepted: 2020-02-19 • Prepublished online: 2020-02-28 
Based on this issue and the subsequent interconnection of theoretical bases with nursing practice, we subsequently set a target focus; the aim of which was to find out the effectiveness of individual elements of the Wagner model in the care of patients with diabetes mellitus. The concept of this model is based on the relationship between informed, activated patients, and prepared, proactive healthcare providers. This means that the patient is motivated, has the information, skills and courage to make and manage effective health decisions and that the healthcare provider has the necessary patient information, decision support and resources for quality care. In all its elements and activities, nurses around the world play a leading role (Larsen, 2019).

The nurse must be a partner to the physician in the area of education, and should have an adequate amount of necessary information that can be effectively communicated to the patient. Education takes several forms and methods, but assumes a human approach with decency and respect for each patient (Puteková et al., 2016). Nurses are expected to be prepared to perform the various roles and interventions associated with comprehensive nursing care provision (Martinková and Kabátová, 2015).

Taking care of patients with diabetes mellitus was a prototype for CCM. This model aims to transform the care of patients with chronic illnesses and improve the organization of care for chronic illnesses through patient education and support, upgrading skills and the use of the registry of the healthcare information system. The current model has been expanded by System 5 - community, and System 6 - healthcare systems, into six elements that work together to strengthen the mediator-patient relationship and to improve healthcare outcomes (Baptista et al., 2016). In order to assess the effectiveness of provided care in chronic illness from the patient's perspective, we followed the recommendations of the ICIC study members.

\section{Materials and methods}

For our research, a quantitative research design was chosen, based on a questionnaire survey. The selection of respondents was stratified. The nature of this method is the basic set distributed by essential characters (Gavora et al., 2010). In our case, it is the residence of a patient with diabetes mellitus. The Association of Diabetics of Slovakia (ZDS) consists of 33 basic organizations, which evenly cover the whole Slovakia. The response rate of questionnaires was 1,511 , which represents $91.6 \%$.

Patients diagnosed with diabetes mellitus formed a core set of our research. According to precise specifications, patients with DM were included that have diabetes mellitus type 1 or 2; and at the same time are members of the ZDS, are being followed up at the appropriate diabetes clinic (and visit it at least once a year), and are treated with oral anti-diabetics or insulin either using insulin pens or an insulin pump. The exclusion criterion was not having type 1 or 2 diabetes; i.e. patients with gestational diabetes, MODY diabetes, etc. Patients with elevated blood glucose levels who were only treated with a diabetic diet were not included in the study. In the study, we used the standardized PACIC+ questionnaire with the authors' consent. The questionnaire consists of 26 standardized items that had been translated into the Slovak version. Reverse translation instructions were followed. Microsoft Excel and Statistica 12 were used to process the data gathered via the questionnaire. The collected data were first evaluated using descriptive statistics tools. As the sample size of respondents was well above 1,000, the Student's $t$-test and normal distribution test statistic values were almost identical.

In view of the above, we used parametric versions of the tests to verify the hypotheses. We used Student's $t$-test to verify the relationship between the numerical variable and the dichotomous variable. We verified the relation of the numerical variable and the multivalued nominal variable with the help of a one-factor ANOVA analysis. When deciding on the validity or rejection of the null hypothesis, we used the significance level $\alpha$ equal to 0.05 , which is the most commonly used number.

\section{Results}

In this paper, we present one of the partial objectives of the research, in which the assumption was defined as follows: "The effectiveness of caring for a patient with DM in the context of CCM model depends on the type of treatment being applied to the patient."

A total of 1,511 respondents participated in the research. The average age of respondents was 53.9 years; the standard deviation was 14.3 years. The youngest respondents were 19 and the oldest $81.53 \%$ of respondents were between 50 and 69 years old. The categorization item that we used in the bivariate analysis as an independent variable was to determine the type of treatment for the questioned DM patients. Respondents were asked to indicate whether they are currently being treated with oral antidiabetics, insulin using insulin pens, or insulin pumps (Table 1).

\begin{tabular}{lcc} 
Table 1. Type of treatment & \\
Type of treatment & Count & $\%$ \\
\hline Insulin pens & 566 & 37 \\
Insulin pump & 379 & 25 \\
PAD & 566 & 37 \\
Total & 1511 & 100 \\
\hline
\end{tabular}

\section{Dependence of the assessment of Element 1 "Self- management by patients with DM" on the type of treatment}

According to our findings, patients with an insulin pump had the most treatment options to think about (mean 3.02). Other patients rated this item significantly lower. The same situation was seen with other items too. In particular, those with an insulin pump confirmed that they could speak about their difficulties in relation to the drugs and their effects (mean 3.21). It is significantly less with patients who use a pen (3.07) or PAD. The average evaluations of the possibility to apply their ideas in the treatment preparation plan show the same trend as the previous items. The item was rated higher (but still negatively) by patients with an insulin pump (mean 2.78), patients on insulin pens rated it lower (mean 2.63) and PAD patients rated it the lowest (2.57). At the same time, there was the lowest difference between patient groups - as the $\beta$-value for this comparison was the highest (Table 2).

\section{Dependence of the assessment of Element 2 "Design of care by patients with DM" on the type of treatment}

In this element, we calculated the differences significant at all common significance levels. The greatest differences were found in patients' satisfaction with the overall organization 
Table 2. Items of the Patient self-management element by treatment type

\begin{tabular}{|c|c|c|c|c|c|c|c|c|}
\hline \multirow{2}{*}{$\begin{array}{l}\text { 1. Element } \\
\text { Self-management of the patient }\end{array}$} & \multicolumn{3}{|c|}{ Mean } & \multicolumn{3}{|c|}{ Standard deviation } & \multirow{2}{*}{$\mathrm{F}$} & \multirow{2}{*}{$p$-h. } \\
\hline & pen & pump & PAD & pen & pump & $\mathrm{PAD}$ & & \\
\hline Provided treatment options for reflection & 2.80 & 3.02 & 2.70 & 1.28 & 1.29 & 1.33 & 6.90 & 0.001 \\
\hline $\begin{array}{l}\text { Call to talk about your difficulties with medicines and their } \\
\text { impact }\end{array}$ & 3.07 & 3.21 & 2.97 & 1.32 & 1.21 & 1.25 & 3.90 & 0.021 \\
\hline Concepts of care when drawing up a treatment plan & 2.63 & 2.78 & 2.57 & 1.32 & 1.21 & 1.28 & 3.14 & 0.043 \\
\hline Patients' self-management & 2.83 & 3.00 & 2.75 & 1.20 & 1.14 & 1.11 & 5.58 & 0.004 \\
\hline
\end{tabular}

of care. The most satisfied patients were those with an insulin pump (mean 3.60), patients on insulin pens were less satisfied (mean 3.33), and the least satisfied were patients treated with PAD (mean 3.17). We also see very significant differences in the provision of written material on how to improve their health. The best rating comes from patients on the insulin pump (3.56), a less positive rating from patients on the pen, and the least positive from patients on the PAD (3.16). Mi- nor differences, although also significant, were found in the last item of the element. The differences are less significant; the $p$-value of 0.032 is only just below the significance level. Patients with an insulin pump received significantly better explanations about how they should take care of themselves to improve their health. As Table 3 demonstrates, the mean of this group is 3.40 , whereas the mean of the other two is lower and almost the same (3.23 and 3.21).

Table 3. Items of care system design element by type of treatment

\begin{tabular}{|c|c|c|c|c|c|c|c|c|}
\hline \multirow{2}{*}{$\begin{array}{l}\text { 2. Element } \\
\text { Design of the care system }\end{array}$} & \multicolumn{3}{|c|}{ Mean } & \multicolumn{3}{|c|}{ Standard deviation } & \multirow{2}{*}{$\mathrm{F}$} & \multirow{2}{*}{$p$-h. } \\
\hline & pen & pump & $\mathrm{PAD}$ & pen & pump & $\mathrm{PAD}$ & & \\
\hline Satisfaction with the organization of care & 3.33 & 3.60 & 3.17 & 1.16 & 0.89 & 1.29 & 16.16 & $1.1 \mathrm{E}-7$ \\
\hline Providing written material on how to improve your health & 3.34 & 3.56 & 3.16 & 1.20 & 1.03 & 1.26 & 12.93 & $2.7 \mathrm{E}-6$ \\
\hline Influence of patient self-care on health condition & 3.23 & 3.40 & 3.21 & 1.19 & 1.02 & 1.27 & 3.44 & 0.032 \\
\hline Care system design & 3.30 & 3.52 & 3.18 & 1.02 & 0.86 & 1.13 & 12.73 & $3.3 \mathrm{E}-6$ \\
\hline
\end{tabular}

\section{Dependence of the assessment of Element 3 "Supporting decision-making by patients with DM" on the type of treatment}

In this area, the groups of patients treated with different treatments generally agreed. We found a significant difference in only one item of the element: in the provision of a treatment plan. It is quite understandable that patients treated with an insulin pump ranked the highest in this area, when its correct use and adjustment requires much more precise instructions than insulin pen dosage or even drug dosage determination. The provision of a treatment plan copy was rated most highly by patients treated with an insulin pump (2.92), lower by patients on insulin pens (2.57) and the lowest by patients treated with PAD (2.38). The difference in this item is very significant since the $p$-value is lower than all common levels of significance. A significant difference, although with a higher $p$-value, was found in another element item. The interest of healthcare professionals in patients' habits of taking care of their health was again more frequent in patients with an insulin pump (3.05), less in patients on insulin pens (2.95) and the least in patients on PAD (2.79). In the other items, the responses of patients from different groups are similar. Overall, however, the average of the scores is highest in the insulin pump patient group, and the difference from the other groups is relatively small or the internal variance in the group is too large to be considered significant. The Decision Support Assessment is the same across all groups and no significant differences among patient groups by treatment type were confirmed (Table 4).

\section{Dependence of the assessment of Element 4 "Counselling and problem solving by patients with DM" on the type of treatment}

The overall score in each group varies significantly, as the $p$-value for the dimension is 0.0006 . This difference of attitudes is manifested mainly in two lines. According to respondents, the patients that are more likely to be helped to develop a plan in difficult times are those treated with an insulin pump (3.20), less likely to be helped are patients treated with insulin pens (3.01), and the least likely to be helped are patients on PAD (2.73). There are also significant differences in providing assistance in drawing up a plan for everyday life. Again, the best rating was given by patients on the insulin pump (3.31), a lower rating by patients on the insulin pens (3.16), and the lowest by patients on the PAD (2.91). In the other two items considering the patient's values and traditions in medical recommendations or requiring the nursing staff to describe the impact of the disease on life - the assessments of the different patient groups did not differ significantly. Thus it can be said that there are significant differences in the fourth element between patients with different types of treatment - especially in terms of drawing up a plan for routine or difficult life. In addition, the individual approach is generally the same for all types of treatments (Table 5). 
Table 4. Items of decision support element by treatment type

\begin{tabular}{|c|c|c|c|c|c|c|c|c|}
\hline \multirow{2}{*}{$\begin{array}{l}\text { 3. Element } \\
\text { Decision support }\end{array}$} & \multicolumn{3}{|c|}{ Mean } & \multicolumn{3}{|c|}{ Standard deviation } & \multirow{2}{*}{$\mathrm{F}$} & \multirow{2}{*}{$p$-h. } \\
\hline & pen & pump & $\mathrm{PAD}$ & pen & pump & PAD & & \\
\hline Providing a copy of the treatment plan & 2.57 & 2.92 & 2.38 & 1.26 & 1.32 & 1.26 & 20.65 & $1.4 \mathrm{E}-09$ \\
\hline Questions about health care habits & 2.95 & 3.05 & 2.79 & 1.23 & 1.14 & 1.32 & 5.30 & 0.005 \\
\hline The challenge of setting goals & 2.75 & 2.91 & 2.74 & 1.29 & 1.12 & 1.29 & 2.68 & 0.069 \\
\hline Helping to set goals to improve habits and exercise & 2.96 & 3.08 & 3.05 & 1.31 & 1.24 & 1.32 & 1.05 & 0.349 \\
\hline Recommend a self-support group / participate in lectures & 2.93 & 2.95 & 2.92 & 1.39 & 1.26 & 1.32 & 0.07 & 0.936 \\
\hline Decision support & 2.83 & 2.98 & 2.77 & 1.12 & 1.07 & 1.06 & 3.29 & 0.051 \\
\hline
\end{tabular}

Key to the significance of statistical results: $p$-value $<0.05$.

Table 5. Items of element counselling and problem solving by treatment type

\begin{tabular}{|c|c|c|c|c|c|c|c|c|}
\hline \multirow{2}{*}{$\begin{array}{l}\text { 4. Element } \\
\text { Counselling and problem solving }\end{array}$} & \multicolumn{3}{|c|}{ Mean } & \multicolumn{3}{|c|}{ Standard deviation } & \multirow{2}{*}{$\mathrm{F}$} & \multirow{2}{*}{$p$-h. } \\
\hline & pen & pump & $\mathrm{PAD}$ & pen & pump & $\mathrm{PAD}$ & & \\
\hline Assistance in drawing up the plan in difficult times & 3.01 & 3.20 & 2.73 & 1.19 & 1.24 & 1.32 & 16.60 & $7.4 \mathrm{E}-08$ \\
\hline Providing assistance in drawing up a daily life plan & 3.16 & 3.31 & 2.91 & 1.16 & 1.23 & 1.32 & 12.78 & 3.1E-06 \\
\hline $\begin{array}{l}\text { Patient values and traditions are considered in the } \\
\text { recommendations }\end{array}$ & 3.03 & 3.05 & 2.92 & 1.27 & 1.26 & 1.32 & 1.50 & 0.222 \\
\hline Desired to describe the impact of the disease on life & 2.91 & 2.97 & 2.85 & 1.28 & 1.19 & 1.33 & 1.01 & 0.365 \\
\hline Advice and troubleshooting & 3.03 & 3.13 & 2.85 & 1.07 & 1.12 & 1.17 & 7.53 & 0.0006 \\
\hline
\end{tabular}

Key to the significance of statistical results: $p$-value $<0.05$.

\section{Dependence of the assessment of Element 5 "Coordination of care by patients with DM" on the type of treatment}

The same two items in element 4 influenced the overall result in element 5 . In our system, the recommendation of a nutritional assistant, educator or counsellor is usually an exceptional rather than a common practice, but it is most common in patients with an insulin pump since the mean 3.06 of this group is the highest. It is lower in the group of patients on insulin pens (2.88), and the lowest in patients with PAD. The differences between groups are statistically significant. There are also significant differences in the assessment of the interest of a diabetologist in the results of follow-ups by other experts. According to respondents, the highest ratings are in the insulin pump group (3.73), a lower rating is seen in patients on insulin pens (3.54), and the lowest in patients on PAD (3.44).
However, in the other three items, the ratings of the different groups are almost the same (Table 6).

\section{Dependence of the assessment of Element 6 "Healthcare system by patients with DM" on the type of treatment}

The results within this element are quite interesting. Insulin pump patients (mean of 3.07 and 2.96) best rate the items representing the first step " 5 A's" of the "ask" model. Patients on insulin pens rated them a little worse (mean of 3.04 and 2.82). In addition, they are again ranked the worst by patients on PAD (mean of 2.86 and 2.67). The trend in the second stage of the model - "advise" - is similar. To give recommendations for support was ranked the best by patients with an insulin pump (2.89). Patients on insulin pens (2.84) gave almost the same score. Again, patients on PAD rated this item the worst

Table 6 Items of care coordination element by treatment type

\begin{tabular}{|c|c|c|c|c|c|c|c|c|}
\hline \multirow{2}{*}{$\begin{array}{l}\text { 5. Element } \\
\text { Coordination of care }\end{array}$} & \multicolumn{3}{|c|}{ Mean } & \multicolumn{3}{|c|}{ Standard deviation } & \multirow{2}{*}{$\mathrm{F}$} & \multirow{2}{*}{$p$-h. } \\
\hline & pen & pump & $\mathrm{PAD}$ & pen & pump & PAD & & \\
\hline Recommended nutrition assistant, educator or counsellor & 2.88 & 3.06 & 2.63 & 1.36 & 1.46 & 1.34 & 11.61 & $9.9 \mathrm{E}-06$ \\
\hline Interest in the results of inspections with other experts & 3.54 & 3.73 & 3.44 & 1.09 & 0.89 & 1.18 & 8.13 & $3.1 \mathrm{E}-04$ \\
\hline Recommendation of community programs & 2.87 & 2.95 & 2.79 & 1.31 & 1.29 & 1.36 & 1.72 & 0.180 \\
\hline $\begin{array}{l}\text { Contacting the treating team, with the aim of finding out } \\
\text { how well the patient is }\end{array}$ & 3.04 & 3.02 & 2.93 & 1.26 & 1.18 & 1.39 & 1.22 & 0.297 \\
\hline $\begin{array}{l}\text { Information on how examinations with other professionals } \\
\text { helped with treatment }\end{array}$ & 3.53 & 3.53 & 3.47 & 1.17 & 1.21 & 1.27 & 0.44 & 0.643 \\
\hline Coordination/community & 3.17 & 3.26 & 3.05 & 1.00 & 1.02 & 1.02 & 4.99 & 0.007 \\
\hline
\end{tabular}

Key to the significance of statistical results: $p$-value $<0.05$. 
(2.70). The third step "agree" brought completely different results. This level was best rated by patients on PAD (3.37), worse by patients on insulin pens (3.25), and surprisingly the lowest by patients with an insulin pump (3.16). Further results were provided by the next stage of the " 5 A's" model "assist". The setting up of targets for coping with the disease is carried out by the nursing staff - and is most often done with diabetic patients on insulin pens. The rating of this group is the highest (mean 3.21). This grade was rated worse by patients with an insulin pump (3.08), and the worst by patients on PAD (2.88). Providing a progress logbook - as the last step "arrange" - was again best rated by insulin pump patients (3.58), worse by patients on insulin pens (3.43), and the worst by patients on PAD (3.33). Insulin pump patients and insulin pen patients generally rated the healthcare systems element the same (mean 3.12 and 3.10). Their functioning is considered weaker by patients on PAD. In this group, the average is 2.97. Overall, the differences are statistically significant. Also significant are the individual items of this element. The only exception is the provision of recommendations for family and community support - where the $p$-value is just above the significance level (Table 7).

Table 7. Items of healthcare systems element by type of treatment

\begin{tabular}{|c|c|c|c|c|c|c|c|c|}
\hline \multirow{2}{*}{$\begin{array}{l}\text { 6. Element } \\
\text { Healthcare systems }\end{array}$} & \multicolumn{3}{|c|}{ Mean } & \multicolumn{3}{|c|}{ Standard deviation } & \multirow{2}{*}{$\mathrm{F}$} & \multirow{2}{*}{ p-h. } \\
\hline & pen & pump & $\mathrm{PAD}$ & pen & pump & PAD & & \\
\hline The challenge to discuss the necessary topics for the patient & 3.04 & 3.07 & 2.86 & 1.24 & 1.15 & 1.17 & 4.68 & 0.009 \\
\hline $\begin{array}{l}\text { The carers are interested in the family and social situation } \\
\text { of the patient }\end{array}$ & 2.82 & 2.96 & 2.67 & 1.24 & 1.39 & 1.29 & 5.69 & 0.003 \\
\hline $\begin{array}{l}\text { Provide recommendations for family and community } \\
\text { support }\end{array}$ & 2.84 & 2.89 & 2.70 & 1.27 & 1.37 & 1.26 & 2.82 & 0.060 \\
\hline Explanation of the impact of activities on health & 3.25 & 3.16 & 3.37 & 1.17 & 1.14 & 1.22 & 3.67 & 0.026 \\
\hline Setting targets for disease management & 3.21 & 3.08 & 2.88 & 1.19 & 1.20 & 1.30 & 10.39 & 3.3E-05 \\
\hline Providing a log to record progress & 3.43 & 3.58 & 3.33 & 1.24 & 1.01 & 1.36 & 4.64 & 0.010 \\
\hline Clinical systems & 3.10 & 3.12 & 2.97 & 0.99 & 1.05 & 1.01 & 3.47 & 0.031 \\
\hline
\end{tabular}

By examining the dependence of the evaluation of the effectiveness of care for a DM patient in the context of CCM with the type of treatment, we found that there is a significant relationship among variables. Most elements are rated best by patients treated with an insulin pump. On the contrary, patients treated with antidiabetics report the worst rating.

\section{Discussion}

The incidence of diabetes mellitus is increasing worldwide. As the population ages, it is expected that the number of patients will increase further. Currently, in the EU, about $10 \%$ of the population suffer from the disease, with the assumption of an increase to $16.6 \%$ by 2030 . In Slovakia, we register nearly 400,000 patients with diabetes mellitus disease. In this context, early diagnosis and treatment of this disease are of crucial preventive importance to its later complications. It is considered proven (EBP - evidence based practice) that early intensive treatment during the initial 10-15 years of the disease brings substantial benefits in terms of reducing, delaying and slowing the development of complications by more than $40 \%$. This effect also persists in later periods; including eventual worsening of disease control later (MZ SR, 2019).

We realize that nursing as a science can only progress if the evidence-based results are implemented in practice. It is the quality contribution to the work of nurses. We agree with the assertion that nursing plays an irreplaceable role in helping chronically ill diabetic patients - offering them their own ways of activity aimed at promoting and maintaining health (Majerníková et al., 2017).

In patients with diabetes mellitus, health education is an important part of the nurse's competence. It is assumed that nurses' participation in the implementation of a care that uses the CCM model (which is based on the theory of human needs) will raise the awareness of people with diabetes mellitus. It is about the quality of self-management, their need for changes in their lifestyles, and strengthening their problematic state so that they accept their situation and believe they can change their reality (Thangkratok, 2018). In the evaluation of self-management by type of treatment, patients with an insulin pump evaluated the item the best and patients treated with oral antidiabetics the worst. For comparison we present the research of Fitzgerald et al. (1998), confirming the presumption that insulin-treated patients achieved better outcomes in different areas of self- care in the context of diabetes mellitus than PAD- treated patients. According to our findings, patients with an insulin pump were given the most options for rethinking treatment and talking about their drug-related problems.

A study by Khairnar et al. (2018) asserts that the inevitable clinical skill of the physician is to provide information to the patient at an individual level, clearly and together with the patient to consider treatment options. The system striving for the improvement of care for chronically ill patients must be motivated and ready to change in terms of its overall organization. It must take the improvements of care as an important task and convert this into purely progressive objectives and policies dealing with the implementation of effective improvement strategy comprising the use of incentives that encourage extensive redesigning of the system of care. Effective organizations try to prevent mistakes and problems in care by reporting and studying errors, which in turn leads to applying appropriate changes to their system (Davy et al., 2015).

When comparing the design of the CCM care system, we can conclude that all patient groups rated it positively. However, patients with the insulin pump were most satisfied. The greatest differences were found in patients' satisfaction with the overall organization of care. We also observed very signif- 
icant differences in the provision of written material about how to improve health; where the top five ratings come from patients with the pump. As Professor Edelman said at the European Association for the Study of Diabetes in Berlin in 2012, the rapid pace of technological progress is a great promise to a continuous innovation and further improvements in the care of patients with diabetes mellitus in the future. The education of patients with diabetes mellitus regarding their own responsibility for self-management should provide them with sufficient and comprehensible information to be able to make informed decisions about their treatment so that they can modify their behaviour to achieve therapeutic goals at their own discretion (Uličianský, 2016).

When evaluating decision-making support by treatment type, the results of our research were negative. Respondents with the insulin pump rated the items least negatively and respondents with the PAD the most negatively - but only in the case of two items. After statistical processing of all items in this element, we did not confirm significant differences among patient groups by treatment type for the following items: challenge for setting up goals; assistance in setting up goals aimed at improving habits and exercise; recommendation to contact a specific group/attend a lecture. In the research of Murat and et al. (2003), only 6\% of respondents understood self-management goals that are important for future decisions. Also, the study of Funnell and Anderson (2004) points out that participation in decision-making is one of the important components in cooperating care, but it is carried out only in one-quarter of all outpatient visits. According to their other claims, secondary healthcare is unlikely to be any better. Expert advice is a sensitive examination of the inner world of a man, re-experiencing hurtful and damaging experience in a safe and careful relationship (Bukovská et al., 2014). The chronic care model in this element describes that all patients with chronic illness make decisions that affect their health.

Effective support for self-management means more than telling patients what to do. It is important to realize the central role of the patient in the care of his/her own health. This includes the use of proven programs that provide basic information, emotional support, and strategies for living with a chronic disease. A common approach is important where providers and patients work together to define problems, prioritize, set goals, and develop treatment plans that take into account patient values and traditions (Davy et al., 2015).

In identifying the differences in counselling and problem-solving evaluations by treatment type, we note that there are significant differences in the fourth element among patients with different types of treatment, especially in terms of designing a plan for common or difficult periods of life. The individual approach is generally the same for all treatments. In the other two items - considering the patient's values and traditions in medical recommendations or requiring the nursing staff to describe the impact of the disease on life - the assessments of the different patient groups did not differ significantly. This is not a positive finding. To mitigate potential impacts, an early solution to the risks that a life with diabetes mellitus brings is needed. We agree with the conclusion of the research by Hudáková and Derńárová (2006, p. 17) that "for diabetics, we recommend permanent contact with a diabetology nurse, educational meetings, diabetes societies, email communication for diabetics and internet-mediated programs (for technically skilled persons and media device owners)". Coordination of care is the deliberate organization of patient care activities between two or more participants involved in the care of a patient with chronic disease. In this definition, all providers working with a proportion of the patient have important clinical data and have clear and established expectations about their roles. Equally important is that they work together to provide information to patients and their families to ensure effective recommendations and behavioural change in the favour of the patient (Davy et al., 2015).

Again, respondents with an insulin pump better evaluated the item Respondent Care Coordination by treatment type. Most often, a nutrition assistant or educator was recommended to patients with an insulin pump. There are also significant differences in assessing the interest of a diabetologist in the results of follow-ups of other professionals. We asked our respondents whether this information was provided to them, but the outcome was unfavourable as the respondents expressed a slight disagreement with this statement. More precisely, $43 \%$ of respondents were positive. This finding is better than the conclusion of Majerníková (2011), where only 30\% of respondents in her research sample reported that they could consult with their nutrition assistant on their diabetic diet. Neither of these findings are gratifying when we realize that a large number of factors affect the control of diabetes - which may also be potential predictors of blood glucose levels in diabetics. According to respondents, the highest score in our research was in the pump group (mean 3.73), lower interest was seen in patients on a pen (mean 3.54) and the lowest on PAD (mean 3.44). The health system is based on the " 5 A's" model: ask - advise - agree - assist - arrange, which was often used to strengthen self-management support and link to community resources. The most important thing is to listen to the patients - ask what they need to improve the interaction and the treatment of the disease (Tol et al., 2015). Among the three groups of patients classified according to the method of treatment, patients with an insulin pump assessed the " $5 \mathrm{~A}$ 's" model the best. Nearly the same score was obtained in the group of patients on insulin pens. Patients on PAD evaluated the functionality of healthcare systems the worst.

\section{Limitations}

We see the research limits in a small research sample, as according to the NCZI in 2017, 354,726 diabetics (165,285 men, 189,441 women) were registered in diabetologic outpatient clinics in Slovakia (NCZI, 2018).

\section{Conclusions}

The Chronic Care Model is designed to help to improve patients' health practices by changing the routine outpatient care through six interrelated system changes of the model based on the evidence. CCM aims to transform day-to-day care for chronically ill patients from acute and reactive to proactive and planned care with a more efficient use of community resources. The first steps of implementing this model in practice should include the consent and opinion of medical doctors and nurses, the establishment of a registry for diabetes mellitus, support of the MoH SR to meet national standards, and the integration of pilot projects for changes in the design of the chronic care system. This model has the potential to improve the effectiveness of care for patients with DM in general practice without adversely affecting patient outcomes. Further research would be needed to assess the cost-effectiveness of the model. 


\section{Ethical aspects and conflict of interests}

The authors declare that the study has no conflict of interests and the ethical aspects of the research were observed. All re- spondents were informed about the purpose of the research and agreed to be included in the research file.

\section{Efektívnost' starostlivosti o pacientov s diabetes mellitus v kontexte Wagnerovho modelu}

\section{Súhrn}

Úvod: V 21. storočí výrazne narastá počet chronických ochorení. Doktor Wagner a kolektív predstavili najvplyvnejší teoretický model starostlivosti o chronicky chorých - Chronic Care Model - CCM.

Dizajn: Predkladaný príspevok analyzuje výsledky získane kvantitatívnym výskumom.

Ciel': Ciel'om kvantitatívneho výskumu bolo zistit', aká je efektívnost' jednotlivých elementov Wagnerovho modelu (CCM) v starostlivosti o pacientov s diabetes mellitus $\mathrm{v}$ závislosti od typu liečby.

Metodika: Celkový súbor tvorilo 1511 respondentov. Výber respondentov bol realizovaný na základe stratifikovaného výberu. Použitým nástrojom pre zber dát bol štandardizovaný dotazník PACIC+.

Výsledky: Skúmaním závislosti hodnotenia efektívnosti starostlivosti o pacienta s DM od typu liečby sme zistili, že medzi premennými je signifikantný vztah. Väčšinu elementov CCM hodnotia najlepšie pacienti, ktorí využívajú inzulínovú pumpu. Naopak, najhoršie hodnotenie uvádzajú pacienti liečení prostredníctvom antidiabetik. Najväčšie rozdiely sme zistili pri spokojnosti pacientov s celkovou organizáciou starostlivosti. Najviac spokojní sú pacienti s inzulínovou pumpou (priemer 3,60), menej pacienti na inzulínových perách (priemer 3,33) a najmenej pacienti liečení PAD (priemer 3,17).

Záver: Wagnerov model má potenciál na zlepšenie efektivity starostlivosti o pacientov s ochorením diabetes mellitus bez toho, aby negatívne ovplyvnil výsledky pacientov.

Kl'účové slová: diabetes mellitus; efektívnost'; chronické ochorenia; ošetrovatel'stvo; Wagnerov model

\section{References}

1. Baptista DR, Wiens A, Pontarolo R, Regis L, Reis WC, Correr CJ (2016). The chronic care model for type 2 diabetes: a systematic review. Diabetol Metab Syndr 8(7): 2-7. DOI: 10.1186/s13098015-0119-z.

2. Bukovská A, Galajda P, Mokáň M (2014). Edukácia a sociálne poradenstvo $\mathrm{v}$ diabetológii. Martin: Osveta.

3. Davy C, Bleasel J, Liu H, Tchan M, Ponniah S, Brown A (2015). Effectiveness of chronic care models: opportunities for improving healthcare practice and health outcomes: a systematic review. BMC Health Serv Res 15(194): 2-11. DOI: 10.1186/s12913-015-0854-8.

4. Fitzgerald JT, et al. (1998). The influence of Treatment Modality and Ethnicity on Attitudes in Type 2 Diabetes. In: Majerníková L', Magurová D (2017). The Effect of Education on the Level Diabetic Self-care among Patients with Diabetes Mellitus Type II on Insulin Treatment. Srbija: Srpsko razvojno udruženje.

5. Funnell MM, Anderson RM (2004). Empowerment and SelfManagement of Diabetes. Clinical diabetes 22(3): 123-127. DOI: 10.2337/diaclin.22.3.123.

6. Garnelo L, dos Santos Lucas AC, Parente RC, Rocha ES, Gonçalves MJ (2014). Organização do cuidado às condições crônicas por equipes de Saúde da Família na Amazônia. Saúde em Debate 38: 158-172. DOI: 10.5935/0103- 1104.2014S012.

7. Gavora P, Koldeová L, Dvorská D, Pekárová J, Moravčík M (2010). Elektronická učebnica pedagogického výskumu. [online] [cit. 2019-05-13]. Available from: http://www.e-metodologia. fedu.uniba.sk/.

8. Hudáková A, Derňárová L' (2006). Podiel ošetrovatel'stva na prevencii komplikácií u diabetikov. Prešov: FZO PU Prešov, 17-20.

9. Khairnar R, Kamal KM, Giannetti V, Dwibedi N, McConaha J (2018). Primary care physician perspectives on barriers and facilitators to self-management of type 2 diabetes. JPHSR 10(1111): 117-123. DOI: 10.1111/jphs.12280.

10. Larsen P (2019). Lubkin's Chronic Illness: Impact and Intervention. Burlington: Jones \& Bartlett Learning.

11. Majerníková L' (2011). Vplyv edukácie prostredníctvom profesionálov na vedomostnú úroveň diabetikov 2. typu. Ošetřovatelství a porodní asistence. 2(1):171-178.
12. Majerníková L', Kaščáková $\mathrm{M}$, Obročníková $\mathrm{A}$, Hudáková $\mathrm{A}$, Kuriplachová G (2017). Kvalita života pacientov s diabetickou retinopatiou. [online] [cit. 2019-05-13]. Available from: http:// www.vedeckekonference.cz/library/proceedings/quaere_2017. pdf.

13. Martinková J, Kabátová O (2015).Ošetrovatel'ská starostlivost v geriatrii I. Trnava: Typi Universitatis Tyrnaviensis.

14. Murata GH, Shah JH, Adam KD, Wendel CS, Bokhari SU, Solvas PA, et al. (2003). Factors affecting diabetes knowledge in Type 2 diabetic veterans. Diabetologia 46(8): 1170-1178. DOI: $10.1007 /$ s00125-003-1161-1.

15. MZ SR (2019). Strategický rámec starostlivosti o zdravie pre roky 2014-2030. [online] [cit. 2019-05-13]. Available from: https://www.health.gov.sk/?strategia-v-zdravotnictve.

16. NCZI (2018). Ročné výkazy za rok 2018. [online] [cit. 201905-13]. Available from: http://www.nczisk.sk/Statistickezistovania/Rocne-vykazy/Rocne-vykazy-za-rok-2018/Pages/ default.aspx

17. Puteková S, Kabátová O, Martinková J, Lajdová A (2016). Faktory ovplyvňujúce vedomosti o výžive u pacienta s antikoagulačnou liečbou. [online] [cit. 2019-05-13]. Available from: https://www.szspektrum.eu/wp-content/ uploads/2017/11/Putekova.pdf.

18. Simmons D, Wenzel H, Zgibor JC (2016). Integrated Diabetes Care: A Multidisciplinary Approach. Switzerland: Springer. DOI: 10.1007/978-3-319-13389-8.

19. Thangkratok P (2018). Role of nurses in implementing chronic care model in subdistrict health promoting hospital. Science, Engineering and Health Studies 13(2): 83-92. DOI: 10.14456/ sehs.2019.9.

20. Tkáčová L', Magurová D, Grešš Halász B, Hudáková A (2019). Wagnerov model starostlivosti o chronicky chorých. Praktický Lékař 98(6): 257-259.

21. Tol A, Alhani F, Shojaeazadeh D, Sharifirad G, Moazam N (2015). An empowering approach to promote the quality of life and self-management among type 2 diabetic patients. J Educ Health Promot 4(13): 4-23. DOI: 10.4103/22779531.154022.

22. Uličianský V (2016). Breviár edukácie diabetika pre internistu. Vnitřní lékařství 62(7-8): 667-670.

23. WHO (2018). Noncommunicable diseases country profiles 2018. Geneva: World Health Organization. Licence: CC BY-NCSA 3.0 IGO. 